\title{
Prevalence of workplace bullying and risk groups: a representative population study
}

\author{
Adriana Ortega • Annie Høgh · Jan Hyld Pejtersen • \\ Helene Feveile $\cdot$ Ole Olsen
}

Published online: 12 March 2009

(C) Springer-Verlag 2009

Erratum to: Int Arch Occup Environ Health (2009) 82:417-426 DOI 10.1007/s00420-008-0339-8

We have discovered three errors in Table 1: (i) the numbers in the first two lines have been interchanged; (ii) in the last line but two the text is wrong as self-employed are not included in sample (the stated number of excluded participants is correct, though); and (iii) the figure for No response should be changed to $N=3,049$ and the corresponding percentage to 38.9. The corrections do not have any influence on our conclusions.

In addition to the original authors, we would also like to include Helene Feveile in the list of authors of the erratum, so that the list of authors is: Adriana Ortega, Annie Høgh, Jan Hyld Pejtersen, Helene Feveile and Ole Olsen.

Table 1 Dropouts and non respondents

\begin{tabular}{lr}
\hline & $N$ \\
\hline Randomly selected from Danish Central Office of Civil Registration & 8,000 \\
Excluded from the study (12 had emigrated, 50 had unknown address, 62 were mentally handicapped, & 166 \\
$\quad 37$ were aboard for a longer period, 2 were dead and 3 people were also in first DPWES* cohort) & 7,834 \\
Total sample & 3,049 \\
No response & 53 \\
Invalid respond; too many missing values or inconsistent data for gender and day of birth compared & 38.9 \\
$\quad$ to the Civil Registration data & 0.7 \\
Valid response & 600 \\
Excluded; not wage earner & 1,732 \\
Excluded; missing value for the bullying question & 88 \\
Final population for the study & 3,429 \\
\hline
\end{tabular}

* Danish Psychosocial Work Environment Study

The online version of the original article can be found under doi: 10.1007/s00420-008-0339-8.

A. Ortega $(\varangle) \cdot$ A. Høgh · J. H. Pejtersen · H. Feveile · O. Olsen National Research Centre for the Working Environment,

Lersø Parkallé 105, 2100 Copenhagen, Denmark

e-mail: aor@nrcwe.dk 